\title{
TAXATION OF MINING AND PETROLEUM
}

\author{
R. D. BELL*
}

\begin{abstract}
The following article discusses various types of business arrangements, such as farmouts, participation agreements, operating agreements, joint ventures, etc., which are frequently used in the natural resources extraction industry. The article then discusses section 66 of the Income Tax Act, and in particular, through a review of case law, legal writings and legislative enactments, the author defines and suggests the proper interpretation of the words "association". "partnership" and "syndicate" which, although used in the Act, are not defined. The author then outlines five significant tax provisions which result from the new partnership tax proposals in the Income Tax Act, and which must be of concern to every business which is involved in the area of natural resource extraction. How to determine whether or not a certain business relationship is a partnership, and the consequent applicability or non-applicability of the new partnership taxing provisions, is outlined and examined. The author suggests, however, that in all likelihood the new partnership taxation provisions would only be applied to the clear-cut cases of partnerships and would not be applied to the various types of business arrangements referred to above. In his concluding comments, the author discusses certain election provisions in the Internal Revenue Code of the United States; encourages the government to specifically exclude the normal extractive industry relationships from taxation as partnerships; and discusses the effect of the new tax provisions in relation to the problem of obtaining American capital.
\end{abstract}

\section{INTRODUCTION}

I have been asked to discuss the various types of business arrangements made for the purpose of finding and producing natural resources. This discussion will later deal with the words, "association", "partnership" and "syndicate" which appear in section 66 of the Income Tax Act. ${ }^{1}$ These are the only words used in the Income Tax Act which presume to describe the nature of relationships common to the extractive industries.

I trust that I may, having regard to the nature of this forum, be forgiven for setting forth a brief description of some of the relationships that exist in the oil and gas industry. My reason for so doing, apart from setting a proper basis for the discussion, is to assist those who may read this paper who are not familiar with the various relationships to comprehend more easily that which follows. Although this discussion is limited to the oil and gas industry, the tax considerations which will later be discussed are substantially common to both the oil and gas industry and the mining industry.

Perhaps an effective manner of presenting all these terms to you is to assume that A (company or individual) has a petroleum and natural gas lease on a given acreage and to progress through what can be described as a representative number of steps to the end of effective production of petroleum substances produced from such lease:

\section{Farmout}

A farmout is, generally, an arrangement between the holder of the lease, A (farmor) and another person, B (farmee) under which the

* Barrister \& Solicitor, Fenerty, McGillivray, Robertson, Brennan, Prowse, Fraser, Bell and Hatch,Calgary, Alberta.

1 R.S.C. 1970-71-72, c. 63. 
farmee will do certain work, which may include exploratory work, and will usually include drilling a well to a certain depth or a certain formation in order to earn an interest in the farmor's lease. Under the simplest type of farmout, the farmee would, upon completing his drilling program, earn an undivided partial interest in the property and would acquire a registrable interest in same. Other forms of interest can, however, be acquired by the farmee. He may acquire a $100 \%$ working interest in the property subject either to an overriding royalty payable to the farmor or to a net profits interest. A working interest is an interest to which is attached the obligation to pay a corresponding share of the drilling, completion and operating costs. A net profits interest is a share of the gross profits less a corresponding share of the operating costs. The overriding royalty or net profits interest is convertible by the farmor to a working interest when the farmee has recovered, out of his share of the sale of the petroleum substances recovered from the well, all his drilling costs and completion costs and all operating costs for the recovery.

\section{Participation Agreement}

$A$ and $B$, instead of their interests being acquired as above described, may combine their efforts to acquire a lease and simply go out and lease certain property. Their agreement will likely set out their relationship with respect to all commonly owned property.

\section{Operating Agreement}

The farmout agreement will provide that the operating agreement, attached as a schedule to the farmout agreement, will apply to all operations conducted for the exploration, development and maintenance of the farmout lands for the production of petroleum substances. Under such an agreement, $A$, for example, could be named as the operator and has a number of defined duties prior to, during and after the drilling of the well and must account to the non-operator, $B$, in respect of all such duties. The agreement will provide that each party shall own his or its proportionate share of the petroleum substances produced from wells operated for the joint account and may, at his or its own expense, take in kind and separately dispose of his or its proportionate share of production exclusive of the production which may be used by the operator in developing and producing operations and of production unavoidably lost. Provision is made for the failure of any party so to take in kind.

The operating agreement will also include a clause as to the relationship of the parties stating that the rights, duties, obligations and liabilities of the parties shall be several and not joint or collective, it being expressed as the intention of the parties that their interests in the lands and the wells, equipment and property thereon shall be held as tenants in common. Then follows a clause similar to the following, namely: Nothing herein contained shall be construed as creating a partnership of any kind, joint venture or association or as imposing upon any party hereto, any partnership duty, obligation or liability to any other party hereto. The agreement will also have a clause providing for waiver of any partition of the lands or sale thereof in lieu of partition and will contain provisions regarding disposition of interests. 


\section{Pooling Arrangement}

This is a pooling by different lessees of their interests in adjacent leases to make up a "spacing unit" so as to permit joint development and also to permit the total "allowable" production to be taken from fewer wells than would have been required for that production if the pooling arrangement had not been made. This results in reduced expenditure and therefore more economic recovery of the petroleum substances. A "spacing unit" is the minimum area prescribed by regulations for the drilling of a well ${ }^{2}$ or for the taking of production. ${ }^{3}$

\section{Unitization}

This is "pooling" on a larger scale. It generally comprises an entire producing field. The purpose is to obtain greater recovery of oil or gas in the most economic fashion. A unit agreement provides that the interests of each royalty owner and working interest owner in the petroleum substances in the unitized zone may be produced as if the unitized zone had been included in a single lease executed by the royalty owners, as lessors, in favour of the working interest owners, as lessees. Production from the whole unit area is allocated to each tract on the basis of tract factors which are agreed upon taking into account known and assumed reservoir characteristics. The unit agreement will provide that the unitized substances shall be delivered in kind at the time and place of production to the working interest owners entitled thereto who, if there is no interference with unit operations, may construct, maintain and operate in the unit area all necessary facilities for taking delivery in kind. This is followed by provisions for the disposition of such substances in the event of failure to take in kind. It is expressly provided, however, that nothing in the unit agreement is to be construed as a transfer or exchange of any interest in the leases, or unitized zone, or in the unitized substances before production thereof. A unit operating agreement is also entered into under which the duties, obligations and liabilities of an operator are outlined.

\section{Joint Venture}

A term commonly used in the oil and gas industry is "joint venture". This term has no specific meaning. Indeed, it is my opinion that any combination of persons to effect a given end constitutes a joint venture. In that sense, the relationships which I have just described would fall under this description. Generally, the term is used, however, to describe relationships which fall short of what is clearly a partnership. It is an operation conducted by two or more parties for the purpose of finding and producing petroleum substances as effectively as possible with each party reserving the right to take his share of production in kind and to dispose of it separately. The joint venturers are usually described by the agreement as not being partners and not being jointly liable. A joint venture is usually carried out for a single venture whereas a partnership contemplates the carrying on of a continuing business. A partnership provides for the sharing of profits realized from the conduct of an oil and gas business whereas the income of a joint venturer comes from the sale of his own share of production.

2 In Alberta, one quarter section for each oil well and one section for each gas well.

Drilling spacing unit or larger. 


\section{GENERAL}

A number of important queries have emerged from the analysis to date affecting the extractive industries. It is certain that many more questions will arise with the passage of time and the accumulation of new experience in the application of the new provisions to factual situations.

I wish to comment upon some of the areas in respect of which queries have risen and, although there are no easy answers to some of those queries, I trust that my comments will have some measure of enlightening value.

Under the former legislation, there was little, if any, tax consequence to whether a taxpayer was regarded as being a member of an "association" or "syndicate" or as being a partner of a partnership. Now, however, the determination becomes very significant indeed. Section 66(15)(b) defines "Canadian exploration and development expenses" incurred by a taxpayer to mean, inter alia: 4

(iv) his share of the Canadian exploration and development expenses incurred after 1971 by any association, partnership or syndicate in a fiscal period thereof, if at the end of that fiscal period he was a member or partner thereof....

It can be seen that this section continues, as did the former Act, to speak of "associations" and "syndicates" which are not defined in the Act and are not referred to elsewhere in the Act. Since case law does not generally recognize either as being a legal entity, it is questionable as to whether expenses can be said legally to have been incurred "by any association ... or syndicate". It is significant to note that these terms are used in the same phrase as is the term "partnership" employed and that all three such terms are used exclusively in reference to the extractive industries. Therefore, a court would conclude that there are some types of relationships in, for example, the oil and gas industry which do not amount to or constitute a partnership but which require some sort of name tag for the limited purpose of determining whether exploration and development expenses were deductible in the year in which a member of an association or syndicate ceased to be a member thereof. There is, literally, no form of relationship that is not an association of persons and I cannot, therefore, really believe that the Department of National Revenue will be very aggressive in attempting to deny the right of exploration and development expense deduction by using these words. It seems logical to me that some form of relationship falling short of, or appearing to fall short of, constituting a partnership but which has established a fiscal period for its accounting purposes is what this subsection aims at. Having regard to what appears to be the only import of the presence of those words in the Income Tax Act, one wonders whether they indeed had to be included. The statement that I have just made does not ignore the fact that if any relationship does constitute a partnership, the partnership provisions come into play, but that is a different matter from the one which I am presently discussing.

Since neither of the two terms describes a legal entity, and since there is no codified common law in Canada with respect to associations and syndicates, lawyers are filled with trepidation (on occasion almost 
amounting to paralysis) at the prospect of describing the same. I wondered, before hieing to the library, whether it would be a useful exercise to analyze these terms by their syllables, thus hoping to derive some hitherto undiscovered but potentially exciting and rewarding meaning which would arm me with great confidence for this dissertation. I was absolutely crestfallen when I took the initial step in this pursuit of examining the first syllable of "association". That syllable conjured up all kinds of thoughts which would have inspired a fascinating tangental discourse (the compulsion to pursue which I have resisted) but left me with a thought direction process which was not purified by my hastening to examine the first syllable of "syndicate". Realizing at this point that I appeared to be immutably rutted in my analysis, I progressed almost stupidly to examine the second syllable of "syndicate" and having done so, realized that the Tax Act was becoming a dirty book. Having regard to the channel of my thought processes so far in this examination, but with the urge to continue the same with respect to terms used in the trade, I moved on to the next and the most common one and was horrified to contemplate, in that light, the full meaning of "joint venture". At this point, I realized this exercise should no longer continue. I was, however, left with the fluttering but not unattractive thought that perhaps we could have the Income Tax Act withdrawn under the obscene literature provisions of the Criminal Code. According to the Supreme Court of Canada, literature is not obscene if it has any redeeming social value.

\section{Partnership}

The best way of approaching a discussion of the three terms in question may be to discuss firstly the characteristics of a partnership and then to attempt to demonstrate how an association or syndicate falls short of that description. The term "partnership" is defined in the Partnership Act of Alberta ${ }^{5}$ (and similarly in other common law provinces) as follows: 6

Partnership means the relationship that subsists between persons carrying on a business in common with a view to profit.

The Act then sets forth various rules to which regard shall be had in determining whether a partnership does or does not exist. They are as follows: ${ }^{7}$

(1) Joint tenancy, tenancy in common, joint property, common property or part ownership does not of itself create a partnership as to anything so held or owned, whether the tenants or owners do or do not share profits made by the use thereof,

(2) The sharing of gross returns does not of itself create a partnership whether the persons sharing the returns have or have not a joint or common right or interest in property from which or from the use of which the returns are derived,

(3) The receipt by a person of a share of the profits of a business is prima facie proof that that person is a partner in the business, but the receipt of the share, or of a payment contingent on or varying with the profits of the business, does not of itself make the person receiving such share or payment a partner in the business, and in particular (inter alia) the receipt by a person of a bad debt or other liquidated amount by instalments or otherwise out of the accruing profits of a business does not of itself make that a person a partner in the business or liable as such and a contract for the remuneration of a servant or agent of a person engaged in a business by a share of the profits of the business does not of itself make the servant or agent a partner in the business or liable as such.

S.S.A. 1970, c. 271.

'. Id. 8. 2(d).

I Id. 
In addition, the following statutory provisions are found in the Alberta Partnership Act: ${ }^{8}$

7. (1) Each partner is an agent of the firm and of his other partners for the purpose of the business of the partnership.

(2) The acts of each partner in carrying on in the usual way business of the kind carried on by the firm of which he is a member, bind the firm and his partners, unless

(a) the partner so acting has in fact no authority to act for the firm in the particular matter, and

(b) the person with whom the partner is dealing knows that the partner has no authority, or does not know or believe him to be a partner.

11. (1) Each partner in a firm is jointly liable with the other partners for debts and obligations of a firm incurred while he is a partner.

These characteristics of agency and joint liability are results of being partners but their obvious presence in an agreement, whether express or implied, would assist in establishing a relationship as a partnership.

There are, as you might well imagine, numerous decisions on what constitutes a partnership and I shall refer to some of the principles that seemed to have emerged from these decisions and to some of the cases which are of assistance in making the important determination. The question of whether there is a partnership in fact must be determined by the real intention of the parties. An alleged partnership may be proved to exist by evidence of various circumstances relating to the question, such as an admission made by anyone of that fact against him, and evidence may be given to corroborate and confirm the fact of this admission. The mere fact that a person has received a share of the profits of a business does not make him a partner in the business but it is an important element in arriving at a conclusion as to the existence of a partnership. Evidence tending to show the existence of a partnership may consist of letters, documents, advertisements, prospectuses, bills of exchange, and other things of like character. One who contributes services but no capital, and one who contributes capital but renders no services, may be partners in a firm. In general, a partner does contribute something, either skill or property, but that is not necessarily so, and one may be a partner in fact without contributing anything.

In Lindley On Partnership, ${ }^{9}$ it is stated: ${ }^{10}$

An agreement to share profits and losses, in the sense of making good the losses if any are sustained, may be said to be characteristic-if not to be the essence- of a partnership contract. Whatever difference of opinion there may be as to other matters, persons engaged in any trade, business, or adventure upon the terms of sharing the profits and making good all losses arising therefrom, are necessarily to some extent partners in that trade, business or adventure; ...

But it does not follow that each of several persons who share profits and losses has all the rights which partners usually have. For example, a person may share profits and losses and yet have no right actively to interfere with the management of the business; or he may have no such right to dissolve as an ordinary partner has; or he may have no right to share the good will of the business on a dissolution; and other instances of restricted rights may be suggested. What in any given case the rights of a particular partner are depends on the agreement into which he has entered; but unless the word "partner" is to be deprived of all definite meaning its proper application to persons who share profits and losses in the sense referred to can hardly be questioned.

\footnotetext{
"Supra, n. 5 .

(12th ed. 1962).

10 Id. at 68 .
} 
The fact that the profit motive is a very strong determining factor is evidenced from many many decisions. For example, the following extracts from the judgment of Jessel, M.R. in Pooley v. Driver ${ }^{11}$ reads as follows: ${ }^{12}$

There could not be a partnership without there was [sic] a commercial business, to be carried on with a view to profit and for division of profits; and as a general rule, I take it, if it fulfills that definition, it is a partnership. I say, as a general rule, that simple definition appears, so far as it goes, to be an accurate definition.

And further he says: ${ }^{13}$

... that the participating in the profits is sufficient proof of partnership if there is nothing to get rid of it. If you find an association, and a contract made by the members of the association that the trade is to be carried on, and that they are to share the profits in certain proportions, then that makes a partnership, unless you can shew from the surrounding circumstances some other relation. It is not impossible to shew some other relation, but, ... it is very difficult to do so. It is often conclusive by itself,not always.

\section{Sir Frederick Pollock in his Digest Of The Law Of Partnership says: ${ }^{14}$}

The true doctrine, as laid down in recent authorities, and now declared by the Act, is that sharing profits is evidence of partnership, but is not conclusive. We have to look not merely at the fact that profits are shared, but at the real intention and contract of the parties as shown by the whole facts of the case. Where one term of a contract creates a right to share profits, it is not correct to take that term as if it stood alone and presume a partnership from it, and then construe the rest of the agreement under the influence of that presumption. Sharing profits, if unexplained, is evidence of partnership: but where there is an express agreement the agreement must from the first be looked to as a whole to arrive at the true intention.

Although this trespasses upon the subsequent brief discussion of what constitutes a syndicate, a 1950 Ontario case, Thrush v. Read ${ }^{15}$ held that the parties to a syndicate agreement had become partners in a joint venture and not merely co-owners of common property. In the agreement, in addition to the joint ownership created by it, there was an intention on the part of the parties to carry on a business in common with a view of profit. In that case, 12 persons entered into a written agreement wherein they were described as "the members of the Sawdust Syndicate". It recited that they had staked mining claims within a defined area, and agreed "that all claims staked, or to be staked, by us, or by or for future members of this syndicate... shall be and are the property of the syndicate as a whole, in which each member has an equal share." The agreement further provided that new members might be admitted with the written consent of the majority of the members, that the management of the syndicate would rest in the hands of two persons until their successors were appointed and that those two persons should have power "to do such things and make such arrangements as they deemed fit and necessary for the welfare of the syndicate". The Court determined that on a true construction of the agreement and in view of all the circumstances disclosed in evidence, it should be held that the parties to the agreement became partners in a joint venture and not merely co-owners of common property. The Judge found that there was a view to profit and that a business was

\footnotetext{
11 (1877) 5 Ch.D. 458.

12 Id. at 472.

13 Id. at 476 .

14 (14th ed. 1947).

13 [1950] O.R. 276.
} 
being carried on since the things that the two managers were authorized to do were, at least the further prospecting of claims and sampling and testing, all with a view to gathering information from which it would be possible to form some estimate of their value, if for no other purpose, at least for the purpose of attempting to sell them. The Judge also determined that if the syndicate granted an option to someone else to do certain work in respect of the claims, the syndicate was still doing what was necessary to carry out its purposes. It is significant, having regard to the form of ownership of oil and gas interests, that in this case each member was restrained from holding as his own any claims which he might thereafter stake in any of the four townships named in the syndicate agreement; such claims also were to be the property of the syndicate. Therefore, agency on the part of each member for the whole group in any such staking was made clear.

In an Alberta case, Sawyers v. Binns, ${ }^{16}$ certain "unit holders" had an undivided fractional interest in certain mining leases and a similar fractional interest in the net production of the mine. The Judge found, as a matter of fact, that the agreements indicated that the ownership was intended to be separated from the actual operation of the mine and that all the unit holder had was an undivided fractional interest in the mine and a similar fractional interest in the net production. The unit holders had nothing to do with the operation of the mine nor did it appear that they had any right to take part in the operation of the mine. It seems that the ratio of this case is that although a sharing of profits existed, the unit holders were not in any fashion involved in the conduct of the business.

\section{Another Canadian authority reads in part: ${ }^{17}$}

The fact that the contract provides for a sharing of the profits, while an important factor in determining the character of the contract, does not of itself make it one of joint adventure. There must be something more, some active participation in the enterprise; some control over the subject-matter or property engaged therein.

The matter of agency in the sense of each partner being an agent of the others also appears to be an important ingredient of a partnership.

In Jaenicke v. Schultz, ${ }^{18}$ in an attempt to determine whether a partnership existed, co-owners of land who merely shared the expense of management and divided the income arising from the land in specified shares were not partners; but if they used the land for the carrying on of the business they would have been partners as regards the business. This statement is made in Sproule v. McConnell: ${ }^{19}$

It appears to be settled law that, while a participation in profits is a strong test of partnership, and while there may be cases where from participation of profits alone, a presumption of partnership arises, yet whether the relation does or does not exist must depend upon the real intention and contract of the parties. The real test appears to be, whether the parties are constituted agents in contracting liabilities in respect of the business which is being carried on.

Professor Baxter ${ }^{20}$ states that the outstanding characteristic of the law of partnership is that it operates through the law of agency, each partner being an agent for the others.

\footnotetext{
16 [1940] 3 W.W.R. 321 .

1: Lewis v. Iron and Metal Exporters Ltd. (1931) 39 O.W.N. 504. This case reported 22 Corpus Juris 847.

in [1924] 3 W.W.R. 325 .

19 [1925] I W.W.R. 609.

${ }^{20}$ (1960) Can. Bar Rev. 451
} 
To summarize, it is essential to every partnership that the following elements exist:

(1) a business is being carried on;

(2) two or more persons are carrying on that business in common;

(3) those persons have a profit motive; and

(4) those persons are agents, each for the other.

\section{Association}

Now let us examine briefly the nature of an "association". The word is defined in March's Thesaurus and Dictionary as "a body of persons united for a common purpose." The Oxford Universal Dictionary defines "association" as "a body of persons associated for a common purpose; the organization formed to effect their purpose; a society," and "the act of associating, or being associated." Funk \& Wagnalls New Practical Standard Dictionary defines "association" as "the act of associating, or the state of being associated; fellowship; combination for a common purpose," and "a body of persons associated for some common purpose; corporation; society; partnership."

The foregoing definitions do not refer to the conduct of a business and do not refer to a profit motive. An examination of a number of cases dealing with associations with respect to their rights and liabilities, their membership, etc. resulted mainly in an analysis of associations for charitable purposes and an analysis of the ability of such associations to be sued, all of which is of no assistance in the present context.

In one case, Ahrens v. Tanners' Association, ${ }^{21}$ several corporations and partnerships formed an unincorporated "association" for the purpose of inducing purchasers of leather to deal exclusively with members of the association. The case did not deal primarily with whether this was a partnership or not but it was necessary to make that determination in order to reach the decision sought and it was held that the association was a partnership, the above-described ingredients being present.

Because much more tax significance attaches to the existence of a partnership than to an "association" or "syndicate", it appears that one does not have to describe what an association is so much as he has to show it is not a partnership.

\section{Syndicate}

The word "syndicate" is used mainly in reference to:

(1) criminal associations on the "Untouchables",

(2) golf club calcuttas, and

(3) steam-room or cocktail party business conversations.

The word "syndicate" is defined in the Oxford Universal Dictionary, in part, as follows:

A combination of capitalists or financiers entered into for the purpose of prosecuting a scheme requiring large resources of capital, especially one having the object of obtaining control of the market in a particular commodity. Hence, more widely, a combination of persons formed for the promotion of an enterprise.

March's Thesaurus and Dictionary defines the term as "a combination of capitalists." Funk \& Wagnalls New Practical Standard Dictionary defines the term as "an association of individuals united to negotiate some business or to prosecute some enterprise requiring large capital."

21 (1903) 6 O.L.R. 63. 
It almost appears from the latter definition that a syndicate or an association is a relationship of persons for a single purpose, or, if more than one purpose, a relationship of persons which, when it becomes active or active in a continuing sense, could constitute a partnership.

Not much law can be found in Canada with respect to what constitutes a syndicate. One English case, Tyser et al. v. The Shipowners Syndicate ${ }^{22}$ describes a number of underwriters who styled themselves "The Shipowners Syndicate". They underwrote a policy of marine insurance, followed by the names of the individual members of the syndicate, against each of which names was written a certain fractional proportion of the total sum insured. The policy contained a special clause entitling the assured "by way of security for the performance of the obligations of the subscribing underwriters and of each and every of them" to the benefit by way of charge upon any policies of reinsurance that might be effected by them. The policy also included a clause which expressed the assurers to bind themselves "each one for his own part". It was held, upon an examination of the contract itself, that the members of the syndicate were individually liable only and were not jointly liable in respect of the insurance amount. Since the question was whether there was joint liability among the members of the syndicate, it was said that if it were left in doubt by the form of the subscription whether the liability were joint or several, certain language in the clause to which I referred showed an intention to enter into a joint undertaking with the hope that the term "syndicate" meant something equivalent to a partnership. The learned Judge said: ${ }^{23}$

... the word 'syndicate' does not indicate in what way the members are acting together....

The Securities Acts of Alberta, British Columbia, Manitoba, Ontario and Saskatchewan provide for the registration and regulation of prospecting syndicates. The Alberta Act contains additional provisions regarding securities issued by commercial syndicates. A prospecting syndicate agreement is one, "where the sole purpose of the syndicate is the financing of prospecting expeditions, preliminary mining development, or the acquisition of mining properties, or any combination thereof". A "commercial syndicate" means, "a combination of persons or companies or both persons and companies formed, with a common view to profit, for the promotion of any mercantile, mechanical or manufacturing enterprise or any enterprise for the development of property, but does not include a prospecting syndicate". Because both provide for limited liability and are exempted from the registration requirements of The Partnership Act, they may have fascinating possibilities so far as extractive industry organizations are concerned.

In conclusion, with respect to this aspect of my address, it is extremely difficult to recite a definite set of rules for the determination of the business relationship of persons. However, I repeat that it appears, after one examines all circumstances surrounding the creation and continuance of a relationship of persons that if the main ingredients previously mentioned are present, a partnership will exist. Failing that, we may or may not find that the relationship is an association or syndicate within the meaning of the Income Tax Act. If a taxpayer is viewed

22 [1896] 1 Q.B. 135.

${ }^{23}$ Id. at 139. 
by the Department as being a member of an association or syndicate he must be such a member at the end of the fiscal period thereof or his exploration and development expense claim for that fiscal period is lost. I have great difficulty in believing that the term "association" was used in section 66 in the sense that it would apply to every kind of relationship which could not be described as a partnership or syndicate and I feel the same way about the meaning of the word "syndicate". I suspect that the words were taken from other legislation for purposes of the former Income Tax Acts and were simply adapted to the new Act without a great deal of thought as to what they meant. They would have absolutely no significance were it not for the peculiar provision that members thereof must at the end of the fiscal period of same be members in order to claim their share of the exploration and development expense.

The effect of sub-paragraph 66(15)(b)(iv) ${ }^{24}$ will, for obvious reasons, greatly influence the timing of the departure of a member or partner from an "association", partnership or "syndicate". If he is not a member or partner at the end of a fiscal period, who, if anyone, may deduct "his share" of the exploration and development expenses incurred by the "association", partnership or "syndicate" in that period? In the absence of the purchaser of his interest being able to establish that he was entitled to deduct same (since he paid the departing member for his interest) it appears that the right to deduct such amount is lost to everyone. If this is the result, "his share" means only the share of exploration and development expenses incurred while the taxpayer was a member or partner of an "association", partnership or "syndicate". Perhaps the real question that should be asked at this point is why that proviso is even included. Surely it would have sufficed to permit any person to deduct his share of any exploration and development expense incurred.

The foregoing statement also invites the question as to the philosophy of the government in attributing to a partnership the characteristics of an entity or a person for tax purposes. It is all very well to have what the legislators might have thought was a complete set of rules to deal with the taxation of partnerships, both with respect to income and capital gains. However, the rules contained in the Act, because of what they don't say as well as because of what they do say, result in my advocating the philosophy that the partnership should have been ignored for tax purposes with the tax consequences of income earning, and capital asset acquisitions and disposals, falling upon the individual members as though they themselves were carrying on the business and owning the assets. Indeed, I am not at all persuaded, in spite of some cogent arguments to the contrary, that a partner does not own, to the extent of his interest, an undivided interest in all the assets of the partnership.

\section{SIGNIFICANT TAX PROVISIONS}

In order to familiarize those persons not aware of the resource properties tax treatment, it should be stated that for a "principalbusiness" company, the cost of a resource property is deductible from income from any source and the amount receivable upon disposal of a resource property is wholly includable in income. Deductibility of

21 Income Tax Act, supra, n. 1. 
acquisition costs of resource properties is limited in the case of nonprincipal-business companies and individuals. Having regard to the new provisions of the Income Tax Act respecting partnerships, it becomes important to consider whether a given relationship constitutes a partnership. Basically, the tax provisions which should concern people in this regard are:

(1) A partnership is deemed to have acquired property from a partner at fair market value and the partner is deemed to have disposed of such property at fair market value. ${ }^{25}$ Assuming a partner has contributed a "resource property" to a partnership, this presumably means that the partnership has an exploration and development expense equal to the fair market value of the resource property since "exploration and development expenses" are defined to include "the cost to him (i.e. a taxpayer) of any ... resource property . . ." 26 Technically, the partnership is not a taxpayer, but I think that the deficient legislation must be read in this fashion since section 66(15)(b)(iv) contemplates that partnerships can incur exploration and development expenses. I used the word "presumably" since one must assume that if the partnership is deemed to have acquired the property "at an amount", such amount will constitute "the cost" of such property for the purpose of section $66(15)(\mathrm{b})$. The partner will have equivalent proceeds includable in his income. If one presupposes a contribution of resource properties equal in value by two or more partners to a partnership, since each partner would have a deduction equal to his deemed income, assuming equal sharing of exploration and development expense, no unfortunate tax result (apart from potential depletion loss which will be discussed later) arises. I am discussing the situation in which resource properties have been acquired after 1971 so that the "relevant percentage" rule set forth in section 59 does not apply. There would, however, be an unhappy tax result where there was a contribution of resource property disproportionate to sharing of exploration and development expense. It is assumed that in the absence of specific provision, the profit sharing percentiles will be applied to exploration and development expense. It is always open, of course, for partners, if they are members of a "Canadian partnership" 27 to make an appropriate election ${ }^{28}$ with respect to the amount at which the property goes into the partnership. That election is not, however, available where one or more partners is or are not resident in Canada and this is usually the case in the oil and gas industry.

(2) The second tax provision of import is that where the partnership has disposed of the property to a partner, the partnership will be deemed to have received the fair market value thereof and: ${ }^{29}$

... the taxpayer shall be deemed to have acquired the property at an amount equal to that fair market value.

Again, making the assumption that I made with respect to the

25. Id. s. 97(1).

${ }^{26}$ Id. s. 66(15)(b)(iii).

27 Id. s. 102.

28 Id. s. 97(2).

29 Id. s. 98(2). 
acquisition by the partnership of property in the first place, the partner would have an acquisition cost which would be equal to his share of the income allocable to him that the partnership was deemed to have received by virtue of such disposition. The Act is not clear, either in section $97(1)$ or in section $98(2)$ that the words ". . . shall be deemed to have acquired the property at an amount equal to . . . fair market value ..." mean that the person so deemed to have acquired the property will have a "cost to him" within the meaning of section 66(15)(b) of the Income Tax Act, but that is how these two sections seem to be interpreted. In this regard, it is to be noted that whereas under the former section $83 \mathrm{~A}$ the acquisition cost of a qualifying property was deductible in respect of an amount paid therefor, now the amount does not have to be paid since it is simply "the cost to him" of a resource property which is considered to be an exploration and development expense incurred by that person. A caution is again introduced here with respect to the other election options which are not open to non-resident partners and care must therefore be taken in moving resource properties in and out of partnerships.

It is distressing to contemplate any effort by the Department of National Revenue to categorize a relationship, short of what is clearly a partnership, (in which each participant regards himself as having always owned the resource property involved in that relationship) as a partnership with a deemed acquisition and/or disposition of such resource property giving rise to the tax results just discussed.

Some Departmental fresh air has accompanied the release of Interpretation Bulletin No. IT-90.30 This was issued on February 9,1973 , subsequent to the presentation of submissions in various fashions respecting the relationships in the extractive industries.

(3) The third matter of tax significance is that an interest in the partnership is considered to be a capital asset, the disposition of which may give rise to tax results with the consequent problem of determining the adjusted cost base thereof. This is not necessarily so for non-resident partners. It appears that the disposal by a non-resident partner of an interest in a partnership, more than $50 \%$ of the value of whose property in the 12 months preceding disposition was not capital property (and resource properties are, by definition, not capital property) is not a disposition of "taxable Canadian property" and is, therefore, exempt from a tax on any capital gain realized thereon. ${ }^{31}$ It appears further that the disposal of an interest in such a partnership cannot be construed as the disposal of the underlying resource property and is therefore exempt from ordinary income tax also. Needless to say, a resident of Canada who disposes of an interest in a partnership will be subject to capital gains tax. It will not be surprising if some astute non-resident takes advantage of this loophole before this obvious flaw is rectified.

The provision in the Notice of Ways and Means Motion to Amend the Income Tax Act issued with the Budget Speech on February 19, 1973, designed to rectify this situation, did not find

Tee Appendix A, infra.

"See Canada Tax Letter, Special Oil and Gas Problems, June 5, 1972. 
its way into Bill C-170 passed by the House of Commons on April 12, 1973 and which received Royal assent on April 18, 1973. The reason for this deletion is not known to me.

(4) A fourth significant result of the new partnership tax proposals is that the depletion base may be adversely affected. A brief description of an operator's depletion is essential for those of you who are unfamiliar with taxation of the oil and gas industry. Under section 65 of the Income Tax Act and section 1201 of the Regulations, a taxpayer who operates a resource is allowed $33 \frac{13 \%}{3}$ of his "production profits" for the year as a depletion deduction. "Production profits" do not include the sale proceeds (actual or deemed) of resource properties. Section 1201(4) of the Regulations states, in effect, that before the depletion percentages apply to production profits, there must be deducted from production profits, inter alia, exploration and development expenses. Therefore, if a partner has, for example, $\$ 300,000$ production profits and an additional $\$ 100,000$ of deemed income from the contribution of a resource property to a partnership, and assuming he has, in respect of that contribution, a corresponding $\$ 100,000$ exploration and development expense (being his share of the partnership exploration and development expense) he must reduce his production profits by $\$ 100,000$ so that depletion is claimed on $\$ 200,000$ only as opposed to being claimed on $\$ 300,000$. Therefore, although the income attributed to a partner by virtue of his contribution of a resource property to a partnership when offset by the corresponding exploration and development expense of the partnership attributed to him appears to be a "wash" for tax purposes, it can have the effect of reducing the depletion base to that partner's substantial tax detriment. The same result arises if a partnership disposes of a resource property to a partner thereof since the partner would have his share of the income deemed to have been received by the partnership and would have an equivalent amount of exploration and development expense. This result should not pertain with respect to what is only deemed income in this circumstance and the Act should be amended to cure this defect. These remarks apply equally to the situation where a company has "rolled over" properties to a "joint exploration company" of which it is a "shareholder corporation".

(5) The fifth matter of tax significance relates to the deduction by a partner of exploration and development expense from Canadian oil and gas income. Subsection 66(3) provides that an individual or a non-principal-business corporation may deduct defined exploration and development expenses from: ${ }^{32}$

(A) his income ... from operating an oil or gas well ...;

(B) his income ... from royalties...;

(C) ... amounts in respect of a Canadian resource property ... that has been disposed of by him....

If, as is suggested above, a partnership is regarded as an entity for taxation purposes, the question arises as to whether, technically, a deduction can be made under subsection $66(3)$ by a 
partner since he may be said not to have income from operating an oil or gas well or from royalties but rather from the partnership. This query, so far as (A) and (B) are concerned, appears to be happily resolved by paragraph $96(1)(e)$ which provides that a partner's income is computed as if the income of the partnership from any source were the income of the partner from that source.

This does not, however, seem to deal with the question of the disposition of a Canadian resource property by the partnership. In that case, the property has not been disposed of by the partner himself. It is obvious from reading the foregoing words that a deduction of Canadian exploration and development expenses can only be made from the disposition proceeds of a Canadian resource property which has been actually "disposed of by him". Although the Department has indicated that it will regard the property disposed of by the partnership as being disposed of by the partners, this is contrary to the nature of a partnership interest within current Canadian tax philosophy. The language of the Act should be clarified to assure that such result is achieved.

The significance of the foregoing tax results is that it is essential either to know that the relationship in which persons are involved in the resource industries is not a partnership or, if it is a partnership, to take the best measures available, whatever they may be. That invites an examination of the relationship in which any participant in the extractive industries finds himself and a categorization of that relationship. That is not an easy task. It would be impossible, under the present circumstances, to analyze all the types of relationships common to the oil and gas industry. However, some comments are offered in respect of some forms of such relationships.

The common ownership of property does not, of itself, create any partnership between the owners whether the owners do or do not share any profits made by the use thereof. The normal type of relationship created by a farmout agreement is one which results in co-ownership and would not result in the establishment of a partnership under our law even though a fiduciary relationship is established between the parties to the agreement.

In Sawyers v. Binns $s^{33}$ it was determined that the purchase of an undivided fractional interest in a mine and of a similar undivided fractional interest in the net production did not alone create a partnership in the operation of the mine nor did the mere acceptance by the purchaser of a part of the net production, which may be considered as equivalent to a rental for his interest, make him a partner of the operator where he had no control over the operations.

However, where three persons agreed to buy an option on mining claims in the name of one of them, and then entered into a written agreement outlining their respective interests and providing for development and disposal of the claims and for distribution of the proceeds, all subject to majority opinion, it was held that they were partners subject to fiduciary obligations to one another and not merely co-owners. ${ }^{34}$

Some assistance in this area is to be derived from an examination of the Midcon Oil \& Gas Limited v. New British Dominion Oil Co.

\footnotetext{
33 Supra, n. 16.

"Regehr v. Kirwan (1963) 40 D.L.R. (2d) 3338 (Y.T.C.A.).
} 
Limited $^{35}$ case where the parties entered into a joint working interest agreement resulting in the development of a gas field. Each party acquired an undivided one-half interest in the mineral rights and the operating equipment and agreed to assume $50 \%$ of all costs. New British Dominion was named operator and was entitled to all production in kind and to make arrangements for its disposal, with liability to account to Midcon for one-half of all production after deducting royalties and expenses. Section 16 of the operating agreement read as follows:

Non operator hereto shall not be entitled to take in kind its share of production or make arrangements for the disposal thereof.

This clause was different from the provisions contained in the majority of present day operating agreements. In order to find a market for the gas, New British joined with others in the promotion of a company which would use the gas for the manufacture of fertilizers, and in the process New British acquired a large block of the shares of the new company. Midcon and the defendant company then participated equally in the incorporation of a pipeline company to supply the gas. Midcon claimed that New British was a trustee for Midcon of one-half of the shares acquired in the fertilizer company. Mr. Justice Primrose, in examining the agreement and looking at all the other facts said: ${ }^{36}$

Having regard to all the provisions of the agreement, I am forced to conclude that there were no provisions in it which established a partnership or that the corporate defendant was in any sense in a fiduciary relationship to the plaintiff as claimed herein.

Section 20 of that operating agreement read as follows:

No agency or partnership relationship is created by or between the parties hereto by the execution of this agreement or the provisions hereof.

It is interesting to note that Mr. Justice Johnson of the Appellate Division of the Supreme Court of Alberta, in upholding that Trial Division decision said: ${ }^{37}$

The learned trial judge is undoubtedly right in holding that the operating agreement does not create a partnership relationship and that quite independently of paragraph 20 which was previously quoted.

He further stated that if in fact agency is created by the agreement a denial of that fact in the agreement will not prevent it being so.

One could go on to discuss the fiduciary relationships in oil and gas joint ventures. An extremely helpful article on that topic has been prepared by Mr. D. A. MacWilliam. ${ }^{38}$ However, the existence of fiduciary relationships does not, of itself, determine that a partnership in fact exists. I suppose that the case could be presented that a partnership exists in respect of many joint venture agreements in that the parties are carrying on business, presumably with a view to profit. However (and I recognize that it is impossible to be definitive in these statements) it occurs to me that a preferred view would be that the parties are simply associating for the purpose of extracting and selling, in the most efficient way possible, the resources owned by each of such parties. To the extent that such position can be supported, it appears to me to be

35 (1956) 19 W.W.R. 317 (Alta. S.C.); aff'd (1957) 2! W.W.R. 228 (Alta. A.D.); Aff'd [1958] S.C.R. 314 (S.C.C.).

(1956) 19 W.W.R. 317 at 330 (Alta. S.C.).

37 (1957) 21 W.W.R. 228 at 234 (Alta. A.D.).

3* (1970) 8 Alta. L. Rev. 233. 
difficult to prove that the relationship between those persons constitutes one of partnership. A close analysis of what might be described as a "typical agreement" is not the purpose of this paper and in any event, time would not permit.

\section{CONCLUSION}

The significance of the application of the Income Tax Act partnership provisions to these relationships, assuming they did constitute a partnership, may be of little or no import in any event. For example, having regard to the fact that an operating agreement or a unit agreement or a unit operating agreement would not terminate until commercial production was no longer feasible, there would presumably be no valuable property distributable upon the termination of such relationship and to the extent that there was, so far as resource properties are concerned, in the normal situation, a "partner" would receive a resource property (giving him an acquisition cost) equal in value to the deemed income in respect of the disposition of same occurring to the partnership and deemed distributed to him. This may, however, affect the depletion base as aforesaid.

If a person disposed of an "interest" (if I can use that description) in any such agreement, he presumably would have disposed of an interest in the resource property or properties and would be required to include the proceeds in his income. I would expect that the Department of National Revenue would be much happier to include the proceeds of disposition of a resource property in his income than to agree with any contention on the part of he who disposed of same that he really had received a capital amount in respect of the disposition of a "partnership interest".

In addition, having regard to the incredible number of different agreements that exist in the oil and gas industry, it seems highly unlikely that the Department of National Revenue would want to start analysing each one from the viewpoint of whether it constituted a partnership. Can you imagine the administrative burden of income tax assessors attempting to determine whether any or all of the dozens or hundreds of agreements of one company constituted a partnership for the purpose of subsequently determining what, if any, tax consequences arose by virtue of the application of the new Income Tax Act partnership provisions?

It seems to me that short of a relationship which can, without much difficulty, be categorized as a partnership, the Department would and should limit its application of such new tax rules to those relationships which are, admittedly, partnerships. For example, there are, as you know, many limited partnerships in the industry. Most of these, to this date, are not Canadian partnerships because not all partners of same are residents of Canada. Since certain elections are not open to them, this means that attention must be paid to the proportion in which properties are contributed (if any are so contributed) to the partnership so that the deemed acquisition cost (exploration and drilling expense) to the partnership will be equal, so far as each partner is concerned, to his deemed proceeds of disposition. In that regard, one wonders whether the agreement should provide that the share of the partnership's exploration and development expense which is allocated to a partner (i.e., deemed exploration and development expense) is in the same 
amount as the value of any property contributed by him. Similarly, as previously pointed out, the distribution of property from a partnership to the partners must be done with an eye to the provisions of section $98(2)^{39}$ which deem the partnership to have disposed of properties at fair market value and the partners to have acquired the same at an amount equal to fair market value. The reason for this, to restate the same, is that the partnership will be deemed to have income on the disposition of these properties which will be allocated to the partners in the percentages in which they share in the partnership income. In order for each such partner to have an equal amount (the deemed acquisition cost of those properties) to offset against such income, the distribution must be made in the same percentage in which the partners share in the partnership income. This is extremely important. In addition, in respect of such partnerships which are not Canadian partnerships as defined in the Act, the various elections of which something has already been said, are not available. To the extent that other considerations permit the same, it is suggested that some partnerships in the resource industry simply carry on until the partnership resource properties have been exhausted.

It is a matter of interest that the Internal Revenue Code of the United States of America deals specifically with the problems of associations and syndicates and partnerships and the taxation of the same. Section 761 of the Code reads as follows:

For purposes of this sub-title, the term 'partnership' includes a syndicate, group, pool, joint venture, or other unincorporated organization through or by means of which any business, financial operation, or venture is carried on, and which is not, within the meaning of this title, a corporation or a trust or a state. Under regulations the Secretary or his delegate may, at the election of all the members of an unincorporated organization exclude such organization from the application of all or part of this sub-chapter, if it is availed of

(1) for investment purposes only and not for the active conduct of a business, or

(2) for the joint production, extraction, or use of property, but not for the purpose of selling services or property produced or extracted,

if the income of the members of the organization may be adequately determined without the computation of partnershid taxable income.

Provision is made for the exclusion of certain unincorporated organizations from the application of all or a part of the provisions of subchapter $\mathrm{K}$ of the U.S. Code which provides for the taxation of partners and partnerships. This can be a beneficial election.

It may be that that type of election would be of assistance to us in Canada. Presumably, the result of such an election would be that a partner would be taxed either as an individual carrying on business on his own behalf or as a company carrying on business on its own behalf. It is at the partner level, and not at the partnership level, that exploration and development expenses and depletion are presently claimed in any event under the new rules. I suspect that the Canadian Government, having adopted the philosophy that a partnership should be treated as an entity for tax purposes, would be loathe to provide any kind of exclusion for one particular industry from the application of the partnership tax provisions. That statement presupposes, of course, that the Government i.e. the elected officials, understood the tax ramifications of the partnership concept when it was introduced in bill form and became legislation and this supposition probably has little basis in fact. If the Government were persuaded that one industry should be

39 Income Tax Act, supra, n. 1. 
entitled to have the provisions excluded, it would probably do so only on the basis that such election be available to every type of industry and that would challenge the entire philosophy of the tax treatment of partnerships included in the Act in the first place. My personal view, and I have intimated so already, is that the Act would do well with amendment to remove the entire philosophy of treating partnerships as separate entities for tax purposes. It seems to me to serve no useful purpose and the removal of this concept, simply invoking the taxability of ordinary income gains and capital gains as they arise, would greatly simplify a taxation system that is unnecessarily complicated already.

I have, since the introduction of the new Act, asserted that the Government should go on record as soon as possible to the effect that the normal extractive industry relationships which I have described would not be regarded as partnerships. Although Interpretation Bulletin No. IT $-90^{40}$ hints at this result, I reiterate my stand in this regard. The last thing this industry needs is the hovering shadow of the over-zealous assessor seeking to collect tax in a fashion that probably was never intended and which makes absolutely no sense.

Another unfortunate result of the new tax provisions, as they exist, arises in respect of the raising of money from our American friends to help us develop our resource industry. There seems to be an increasing trend of major oil and gas companies looking for exploration funds. These funds, to an appreciable extent, come from individual U.S. investors and are advanced by such individuals on the basis that they will have the deduction of their cost together with depletion.

It is my understanding that to obtain such U.S. tax benefits, the U.S. investor (individual or company), in a farmee capacity, must own a $100 \%$ working interest in the well or wells where he is spending a disproportionate part of the cost thereof until recovery of his costs out of production. It is highly unlikely that many large companies with large areas of interest will be disposed to agree to that type of arrangement. The other alternative, in order to give the U.S. investor his maximum U.S. tax advantage, is for him to be a partner in a partnership which owns the resources and which by agreement allocates all deductions to the partner who is putting up the money. The problem arising out of this latter method is that it may be undesirable to have the relationship between the Canadian company and the American investor constitute a partnership with all of the Canadian tax partnership problems arising, whereas for U.S. purposes the relationships must qualify as a partnership in order for the exclusion, to which I have previously referred, to be available and for the aforesaid deduction to be made. It is possible that in attempting to avoid partnership categorization in Canada an agreement may be considered for U.S. tax purposes, not as a partnership, but as an association taxable as a corporation. A number of tests are applied to make that determination. These problems are not incapable of solution but they exist unnecessarily, in my judgment, having regard to my view of the Canadian partnership taxation provisions.

The foregoing comments relate to the main problems which have arisen, so far, from an examination of the new tax legislation as it relates to associations, syndicates and partnerships. Undoubtedly, more will appear.

10 Supra, n. 30. 


\section{APPENDIX "A"}

\section{Department of National Revenue Taxation Interpretation Bulletin}

Income Tax Act - What is a Partnership?

IT-90 Section 96

February 9, 1973

1. The Income Tax Act does not define a "partnership", but outlines the tax consequences if one exists. Section 102 defines what is meant by a "Canadian partnership", but presupposes that there is a partnership. A partnership is not a person, nor is it deemed to be within the meaning of the Act, notwithstanding that section 96 provides that the income of a member of a partnership is computed as if the partnership were a separate person resident in Canada.

2. Generally speaking, a partnership is the relation that subsists between persons carrying on business in common with a view to profit. However, co-ownership of one or more properties not associated with a business, (which under Common Law might be a joint tenancy or a tenancy in common), does not of itself create a partnership, and this is so regardless of an arrangement to share profits and losses. For guidance on whether a particular arrangement at a particular time constitutes a partnership, reference should be made to the relevant provincial law on the subject, and such law will be viewed as persuasive by the Department of National Revenue.

3. A characteristic of a partnership is a sharing of profits of a business as opposed to a sharing of gross returns. Where the share of profits represents the payment of an obligation as opposed to a partnership right to so share, any presumption of partnership relating to the share of profits is rebutted.

4. A joint venture agreement, whereby two or more persons agree that each provides his own property to perform a specific task and receives a specific division of profits from such a task, may be considered a partnership as regards such profits; but as long as the property is not held under joint tenancy or tenancy in common, it is not considered to be partnership property. Thus the capital cost allowance provisions relating to partnership property do not apply.

5. Where several persons form an association for the purpose of carrying out particular business transactions in which they are mutually interested, the association has the characteristic of partnership. However, such persons may associate without each accepting total liability for the association's debts. In these circumstances, contracts may indicate that the associated persons will be liable only for their respective agreed portions of the debts. The existence of such an arrangement is viewed as an indication that a partnership does not exist. One of the original examples of this type of association which does not constitute a partnership is a syndicate of insurance underwriters. Associations or syndicates in connection with natural resource industries often are in the same category.

6. Since a partnership is a relationship between persons carrying on business for profit, the type and extent of a person's involvement in the business is relevant in determining whether he is in reality a partner. 
7. Formal registration of a partnership or limited partnership is not in itself decisive because a declaration of this type does not prevail in partnership law over the actual facts of a situation.

8. Any of the factors mentioned in this Bulletin are not necessarily decisive in themselves, but merely serve as objective criteria on which to base a decision on the existence or non-existence of a partnership. 